Research Article

\title{
Evaluation of effect of alcoholic extract of Tinospora cordifolia on learning and memory in alprazolam induced amnesia in albino mice
}

\author{
Jyothi C. H., Shashikala G.*, Vidya H. K., Shashikala G. H.
}

Department of Pharmacology, JJM Medical College, Davangere, Karnataka, India

Received: 19 July 2016 Accepted: 23 August 2016

*Correspondence to:

Dr. Shashikala G.,

Email: shashiaseni@gmail.com

Copyright: (C) the author(s), publisher and licensee Medip Academy. This is an openaccess article distributed under the terms of the Creative Commons Attribution NonCommercial License, which permits unrestricted noncommercial use, distribution, and reproduction in any medium, provided the original work is properly cited.

\begin{abstract}
Background: Tinospora cordifolia is one of the most versatile shrub with cognitive enhancing effects could be beneficial for treatment of dementia and neurodegenerative diseases like alzheimer's disease. The purpose of study was to evaluate the effect of Tinospora cordifolia on learning and memory in alprazolam induced amnesia in albino mice.

Methods: The study was carried out on albino mice, divided into 4 groups of 6 animals each (either sex, 3-4 months of age, weight 25-30g). Amnesia was induced by administering alprazolam ( $2 \mathrm{mg} / \mathrm{kg}$ body weight for 14 days $)$ in all 4 groups for 14 days from $1^{\text {st }}$ to $14^{\text {th }}$ day. Group 1 was given alprazolam (2 $\mathrm{mg} / \mathrm{kg} / \mathrm{p} . \mathrm{o}$ ) alone for 14 days. In addition, group 2 was given piracetam (400 $\mathrm{mg} / \mathrm{kg} \mathrm{p.o)}$ from $8^{\text {th }}$ to $15^{\text {th }}$ day. Group 3 was given alcoholic extract of Tinospora cordifolia $140 \mathrm{mg} / \mathrm{kg}$, p.o. from $1^{\text {st }}$ to $15^{\text {th }}$ day. Group 4 was given alcoholic extract of Tinospora cordifolia $280 \mathrm{mg} / \mathrm{kg}$, p.o. from $1^{\text {st }}$ to $15^{\text {th }}$ day. The learning and memory of the animals was assessed by employing elevated plus maze (EPM) and step-down type passive avoidance model (SDA).

Results: Results were compared among the different groups using one wayANOVA followed by post hoc Tukey's test. The measured parameters were compared with standard drug piracetam. Tinospora cordifolia at $140 \mathrm{mg} / \mathrm{kg}$ $(\mathrm{p}<0.02)$ and $280 \mathrm{mg} / \mathrm{kg}$ was significant in both models $(\mathrm{p}<0.02)$ and in EPM model, Tinospora cordifolia at $280 \mathrm{mg} / \mathrm{kg}$ showed highly significant result $(\mathrm{P}<0.01)$.

Conclusions: Tinospora cordifolia, Indian medicinal plant useful for treatment of various ailments can also be a useful alternative for treating dementia and associated diseases like alzheimer's disease.
\end{abstract}

Keywords: Tinospora cordifolia, Piracetam, Alprazolam, Alzheimer's disease, Elevated plus maze, Step-down type passive avoidance

\section{INTRODUCTION}

Dementia is defined as an acquired deterioration in cognitive abilities that impairs the successful performance of daily activities. Memory is the most common cognitive ability lost with dementia. ${ }^{1}$ Learning is defined as the acquisition of information and skills, and subsequent retention of that information is called memory. ${ }^{2}$ Memory is the ability of an individual to recall sensory stimuli, events, information etc. to retain them over short or long periods of time and recall the same at a later date when needed. ${ }^{3}$ One of the most common cause of dementia being alzheimer's disease (AD) affecting $10 \%$ of elderly population. $\mathrm{AD}$ is associated with widespread neuronal degeneration involving hippocampus and cognitive changes begins with impairment of memory, spreading to language and visuospatial deficits. ${ }^{1}$ The progressive memory deficits and cognitive impairment affects patient's quality of life.

Tinospora cordifolia is an Indian medicinal plant commonly known as Guduchi, has been used in Ayurvedic preparations throughout the centuries for the treatment of various ailments like general weakness, fever, dyspepsia, gonorrhoea, secondary syphilis, urinary diseases, impotency, gout, viral hepatitis, skin diseases, jaundice, rheumatoid arthritis, and diabetes. ${ }^{4}$

Currently available treatment of $\mathrm{AD}$ includes cholinesterase inhibitors like donepezil, rivastigmine and galantamine. These drugs have only modest efficacy and side effects like GI distress, altered sleep with unpleasant 
dreams, muscle cramping and bradycardia. ${ }^{5}$ There is a need for development of newer and effective drugs in order to improve patient's quality of life. Ayurvedic literature recommends a rejuvenating recipe where Tinospora cordifolia being an important constituent to enhance the memory. ${ }^{6,7}$ With this background the present study has been taken to evaluate the effect of Tinospora cordifolia on learning and memory in alprazolam induced amnesia in albino mice.

The objective of this study was to evaluate the effect of Tinospora cordifolia on learning and memory in alprazolam induced amnesia in albino mice.

\section{METHODS}

\section{Source of test drug}

The whole plant of Tinospora cordifolia was collected from their natural habitat in Davangere city, Karnataka state, India.

\section{Preparation of alcoholic extract of Tinospora cordifolia}

The whole plant was shade dried for one month and then coarse powder was obtained using a mechanical grinder. Coarse powder of $300 \mathrm{~g}$ was successively extracted with $1.5 \mathrm{~L}$ of alcohol, in a soxhlet apparatus at $70-75^{\circ} \mathrm{C}$ each for 10-12 hours consecutively. Alcohol was removed from the extract and a semisolid mass was obtained using water bath. The yield of alcoholic extract was weighed and used for experiment.

\section{Selection of animals}

Albino mice of either sex, weighing around 25-30 g were employed in the present study. They were exposed to alternate light and dark cycle of 12 hours and had a free access to food and water. They were procured from animal house of J. J. M. Medical College, Davangere.

\section{Inclusion criteria}

Healthy albino mice weighing 25-30 gm with normal behaviour and activity. The mice previously unused for any experiment.

\section{Exclusion criteria}

Pregnant and diseased animals were not included in the study.

- Duration of study: 2 months

\section{Drugs and chemicals used}

- Standard drug- Piracetam

- Amnesic drug- Alprazolam

- $1 \%$ Carboxy methyl cellulose.
Drugs and chemicals were procured from local market and were of analytical grade.

\section{Instruments required}

- Elevated plus maze

- Step-down avoidance apparatus

- Oral feeding tube

- Stop watch

\section{Procedure}

Albino mice of either sex, weighing around 25-30 gm were randomly selected. All the animals were kept under laboratory condition for acclimatization period of seven days before carrying out the experiments. Each group of mice was housed separately in a metallic cage and provided with adequate food and water. They were maintained under standard laboratory conditions with natural light and dark cycle, under room temperature.

Study was conducted for 16 days. Experiment was carried out during the $15^{\text {th }}$ and $16^{\text {th }}$ day between $9.00 \mathrm{am}$ and $3.00 \mathrm{pm}$. Animals were divided into four groups of 6 mice each. Study drug piracetam was suspended in $1 \%$ Carboxy methyl cellulose.

Group 1 received amnestic agent alprazolam (2 $\mathrm{mg} / \mathrm{kg} / \mathrm{p} . \mathrm{o})$ alone for 14 days. Group 2 received alprazolam ( $2 \mathrm{mg} / \mathrm{kg}$ p.o) for 14 days with piracetam (400 $\mathrm{mg} / \mathrm{kg} \mathrm{p.o)}$ from $8^{\text {th }}$ to $15^{\text {th }}$ day. Group 3 received alprazolam (2 mg/kg alone p.o) for 14 days with alcoholic extract of Tinospora cordifolia $140 \mathrm{mg} / \mathrm{kg}$, p.o. from $1^{\text {st }}$ to $15^{\text {th }}$ day. Group 4 received alprazolam (2 $\mathrm{mg} / \mathrm{kg}$ alone p.o) for 14 days with alcoholic extract of Tinospora cordifolia $280 \mathrm{mg} / \mathrm{kg}$, p.o. from $1^{\text {st }}$ to $15^{\text {th }}$ day. $^{7-9}$

Piracetam is a nootropic drug, has been used as a standard in many research articles. ${ }^{9}$

Group 1- Treated with alprazolam $2 \mathrm{mg} / \mathrm{kg}$ alone p.o.

Group 2- Alprazolam (2 mg/kg alone, p.o) + piracetam $400 \mathrm{mg} / \mathrm{kg}$ p.o (standard group).

Group 3- Alprazolam (2 mg/kg alone, p.o) + alcoholic extract of Tinospora cordifolia $140 \mathrm{mg} / \mathrm{kg}$, p.o. (test group 1).

Group 4- Alprazolam (2 mg/kg alone, p.o) + alcoholic extract of Tinospora cordifolia $280 \mathrm{mg} / \mathrm{kg}$, p.o. (test group 2).

On $15^{\text {th }}$ day, 90 minutes after the administration of the last dose of drugs in the respective groups, mice were exposed to elevated plus maze and passive avoidance task for acquisition (learning) and retention (memory) was recorded 24 hours later, on the $16^{\text {th }}$ day. 
Laboratory models for testing learning and memory enhancing activity.

\section{Elevated plus maze}

Mazes are the traditional tools in assessing learning and memory performance in laboratory animals. These are used to measure the cognitive performance, notably to evaluate the spatial long term memory in mice and rats.

The apparatus consists of two open arms measuring $16 \times 5$ $\mathrm{cm}$ for mice and two enclosed arms measuring $16 \times 5 \times 12$ $\mathrm{cm}$ with an open roof, arranged so that the two open arms and two enclosed arms are opposite to each other. The maze is elevated to a height of $25 \mathrm{~cm}$. Transfer latency (TL) is a parameter of memory. The transfer latency was defined as the time in seconds taken by the animal to move into one of the enclosed arms. The experiment was performed in 2 stages. On day 15, the day of acquisition testing, each mice was placed at the end of an open arm facing away from the centre. The time taken to enter any one of the closed arms was recorded as transfer latency (TL).

All four legs inside the closed arm were counted as an entry. Cut off time allotted for each mice would be 90 s. Those animals which could not enter the closed arms within the cut off time were excluded from the study. Retention testing was conducted 24 hours after the first trial and transfer latency was recorded in a similar manner as mentioned before. Shortened transfer latency on next day was considered as an index of improvement of memory. ${ }^{2}$

\section{Step-down type passive avoidance test}

The step-down type of passive avoidance task has been used to examine the long term memory based on negative reinforcement. The apparatus consists of a transparent acrylic cage $(30 \times 30 \times 40 \mathrm{~cm}$ high $)$ with a grid floor, inserted in a semi-soundproof outer box $(35 \times 35 \times 90 \mathrm{~cm})$. The cage was illuminated with a $15 \mathrm{~W}$ lamp during the experimental period. A wooden platform $(4 \times 4 \times 4 \mathrm{~cm})$ was fixed in the centre of the grid floor. Electric shocks $(1 \mathrm{~Hz}$, $500 \mathrm{msec}, 40 \mathrm{~V} \mathrm{DC}$ ) were delivered to the grid floor with a commercially available isolated pulse stimulator. The training was carried out in two similar sessions. Each mouse was placed on the platform in the centre of the cage. When the mouse steps down and places all its paws on the grid floor, shock was delivered for 15 seconds. Step down latency (SDL), and the number of flinching reactions and vocalizations were measured. Animals showing SDL of 3-30 seconds during the first training session were preselected for second and retention trails. The second session was carried out 90 minutes after the first. Animals staying 60 seconds on the platform were considered as remembering the task and no longer received electric shocks. The retention test is carried out 24 hours after training, in a similar manner, except that electric shocks were not applied to the grid floor. Each mouse was again placed on the platform, and the SDL was recorded with an upper cut-off time of 300 seconds. Amnestic drugs are expected to decrease the SDL in subsequent trails indicating the impairment of learning and retention tasks. ${ }^{2}$

\section{RESULTS}

Table 1: Comparison between different groups in EPM model.

\begin{tabular}{|llll|}
\hline \multirow{2}{*}{ Groups } & & EPM Model & $\mathbf{1 6}^{\text {th }} \mathbf{d a y}^{\text {th }}$ \\
\cline { 2 - 4 } & Drugs & $\mathbf{1 5}^{\text {day }}$ & Mean \pm SD \\
\hline Group A & Alprozolam only & $72.5 \pm 30.62$ & $65.17 \pm 29.8$ \\
\hline Group B standard & Alprozolam + Piracetam & $70.0 \pm 17.03$ & $52.5 \pm 18.9$ \\
\hline Group C test & Alprazolam + Tc $140 \mathrm{mg} / \mathrm{kg}$ & $81.67 \pm 16.02$ & $49.33 \pm 24.22$ \\
\hline Group D test & Alprazolam + Tc $280 \mathrm{mg} / \mathrm{kg}$ & $66.67 \pm 22.29$ & $33.83 \pm 22.96$ \\
\hline
\end{tabular}

Results expressed as mean $\pm \mathrm{SD}$, $\mathrm{p}$ value $<0.05$ considered significant.

\begin{tabular}{|ll|}
\hline Groups & Tukey's post hoc multiple comparison \\
\hline A versus B & p Value \\
\hline A versus C & $\mathrm{p}>0.12$ \\
\hline B versus C & $\mathrm{p}<0.000$ \\
\hline B versus D & $\mathrm{p}<0.02$ \\
\hline
\end{tabular}


Table 2: Comparison between different groups in SDA model.

\begin{tabular}{|c|c|c|c|}
\hline \multicolumn{4}{|c|}{ SDA model } \\
\hline \multirow{2}{*}{ Groups } & \multirow{2}{*}{ Drugs } & $15^{\text {th }}$ Day & $16^{\text {th }}$ Day \\
\hline & & Mean \pm SD & Mean \pm SD \\
\hline Group A & Alprozolam only & $8.17 \pm 2.93$ & $17.0 \pm 13.34$ \\
\hline Group B standard & Alprozolam + Piracetam & $46.0 \pm 58.42$ & $179.67 \pm 119.69$ \\
\hline Group C test & Alprazolam+Tc $140 \mathrm{mg} / \mathrm{kg}$ & $25.83 \pm 26.23$ & $162.83 \pm 91.96$ \\
\hline Group D test & Alprazolam+ Tc $280 \mathrm{mg} / \mathrm{kg}$ & $7.0 \pm 3.4$ & $135.3 \pm 103.85$ \\
\hline \multicolumn{4}{|c|}{ Results expressed as mean $\pm \mathrm{SD}, \mathrm{p}$ value $<0.05$ considered significant. } \\
\hline \multicolumn{4}{|c|}{ Tukey's post hoc multiple comparison } \\
\hline Groups & & & p Value \\
\hline A versus $B$ & & & $\mathrm{p}<0.05$ \\
\hline A versus $\mathrm{C}$ & & & $\mathrm{p}<0.05$ \\
\hline B versus C & & & $\mathrm{p}<0.02$ \\
\hline B versus D & & & $\mathrm{p}<0.02$ \\
\hline
\end{tabular}

Result was analysed by calculating the mean values, standard deviation and standard error of mean followed by 'Paired $t$ test' to compare between acquisition $\left(15^{\text {th }}\right.$ day) and retention (16 ${ }^{\text {th }}$ day) with in the groups. Differences in $15^{\text {th }}$ and $16^{\text {th }}$ day trial in all four groups were subjected to one way analysis of variance (ANOVA), if results were significant post-hoc Tukey's test was done. $\mathrm{P}$ value of $<0.05$ was considered as significant.

\section{Elevated plus maze test}

Alcoholic extract of Tinospora cordifolia at dose of $140 \mathrm{mg} / \mathrm{kg}$ showed significant decrease in Transfer latency compared to standard drug Piracetam $(\mathrm{p}<0.02)$, whereas Tinospora cordifolia at dose of $280 \mathrm{mg} / \mathrm{kg}$ showed highly significant result $(\mathrm{p}<0.01)$. Results are given in Table 1 and Figure 1.

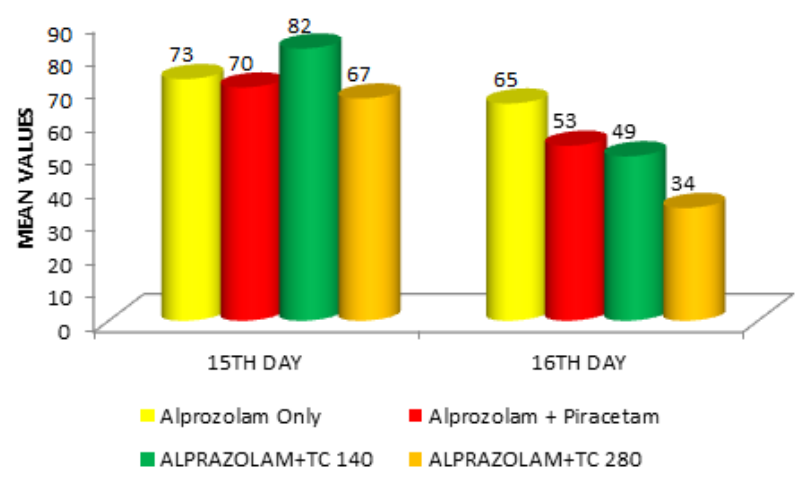

Figure 1: Percentage of mean values of TL in EPM model.

\section{Step-down type passive avoidance test}

Both doses of alcoholic extract of Tinospora cordifolia showed significant result compared to standard drug $(\mathrm{p}<0.02)$. Results are given in Table 2 and Figure 2.

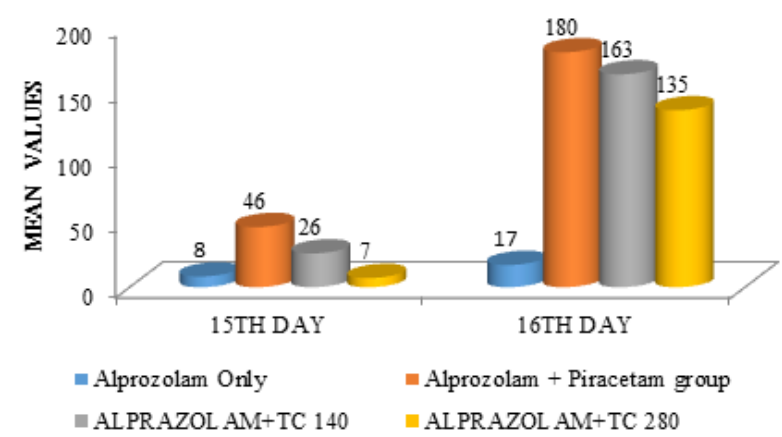

Figure 2: Percentage of mean values of SDL in SDA model.

\section{DISCUSSION}

The present study was undertaken to study the effect of Tinospora cordifolia (Tc) on learning and memory in alprazolam induced amnesic mice. Alcoholic extract of Tc has enhanced cognition in elevated plus maze and stepdown type passive avoidance task. Alprazolam has been used as an amnesic agent. It belongs to the class of Benzodiazepines and has been shown to impair cognitive process. $^{8}$

Tinospora cordifolia is a plant with diverse medicinal properties like anti-diabetic, anti-inflammatory, antiarthritic, anti-oxidant, anti-stress, anti-allergic, antileprotic, anti-malarial, hepatoprotective, immunomodulatory and anti-neoplastic activities. ${ }^{4,10,11}$ Various phytochemical constituents have been identified like alkaloids, diterpenoid lactones, glycosides, sesquiterpenoid, aliphatic compounds, phenolics, and polysaccharides, steroids like tinosporine, tinosporaside, cordifolide, cordifol, heptacosanol, furanolactone tinosporidine, columbin and $\beta$-sitosterol. Choline is one of the important constituent among alkaloids. ${ }^{4}$ 
In our study both the doses of alcoholic extract of Tinospora cordifolia produced significant results compared to standard drug piracetam. A study by Agarwal A, Malini S, Bairy KL, et al. Effect of Tinospora cordifolia on learning and memory in normal and memory deficit rats suggested that Tc may bear a potential use in neurodegenerative disease affecting cerebral neurons and immusuppression induced memory changes. ${ }^{7}$ Another study by Malve HO, Raut SB, Marathe PA, et al. Effect of combination of Phyllanthus emblica (Pe), Tinospora cordifolia (Tc) and Ocimum sanctum on spatial learning and memory in rats suggested that combination of Phyllanthus emblica and Tinospora cordifolia with and without Ocimum sanctum demonstrated nootropic activity in normal and memory impaired rats and both the formulations showed comparable nootropic activity with that of Tc and Pe alone. ${ }^{12}$ The probable mechanism of cognitive enhancement by Tc could be by immunostimulation and increasing the synthesis of acetylcholine which is an important neurotransmitter in learning and memory process. This proposed mechanism of action could be due to supplementation of choline which is an important active constituent of Tc. ${ }^{7}$ Citicholine is a compound derived from choline and cytidine, used as cognitive enhancer, as studies have demonstrated that it causes short-term improvement in memory and behaviour in cerebrovascular disorders it is a supporting report for the proposed mechanism of action of Tc. ${ }^{13}$ Further studies are needed to explore the exact mechanism of action of Tc.

\section{CONCLUSION}

Tinospora cordifolia an Indian medicinal plant with various properties can be a useful alternative and natural source drug for treatment of defective learning and memory and also to other geriatric diseases. Further studies exploring the mechanism of action of Tinospora cordifolia are required to support these observations.

Funding: No funding sources

Conflict of interest: None declared

Ethical approval: The study was approved by the Institutional Ethics Committee

\section{REFERENCES}

1. Alzheimer's disease and other dementias. Kasper, Fauci, Hauser, Lango, Jameson. Harrison's principles of Internal medicine, $19^{\text {th }}$ edition, volume 2 , New Delhi, McGraw-Hill Education; 2015:2598-2608.
2. Animal behavioural models for testing Anti-anxiety and Nootropic agents. S.K. Kulkarni, Hand Book of Experimental Pharmacology, $4^{\text {th }}$ edition, Delhi: Vallabh Prakashan; 2013:40-98.

3. Joshi M, Gaonkar K, Mangoankar S, Satarkar S. Pharmacological investigation of Areca catechu for evaluation of learning, memory and behaviour in rats. Int Curr Pharm J. 2012;1(6):128-32.

4. Margaret E, Neeraja PV. Amruthavalli (Tinospora cardifolia) multipurpose rejunuvator. International journal of Pharmaceutical, chemical and biological sciences. 2013;3(2):223-41.

5. Treatment of Central Nervous System Degenerative Disorders. Laurence L. Bruton, Bruce A. Chabner, Bjorn C. Knollmann. Goodmann and Gilman's Pharmacological Basis of Therapeutics, $12^{\text {th }}$ edition, New York, The McGraw-Hill companies; 2011:60928.

6. Choudhary GP. Immunomodulatory activity of alcoholic extract of Tinospora cardifolia. Int Journal of pharmaceutical sciences. 2015;4(3);357-9.

7. Agarwal A, Malini S. Bairy KL, Muddanna S, Rao. Effect of Tinospora cardifolia on learning and memory in normal and memory deficit rats. Ind $\mathbf{J}$ Pharm. 2002;34:339-49.

8. Parle M, Singh N. Reversal of memory deficits by Atorvastatin and Simvastatin in rats. Yakugaku Zasshi. 2007;127(7):1125-37.

9. Mishra MR, Md. Javed S, Ahmad S, Mohan L, Ahmad MI. Effects of atorvastatin and simvastatin on learning and memory in aged swiss albino mice. Int $\mathbf{J}$ Pharm Sci Rev Res. 2013;23(2):383-7.

10. Saha S, Gosh S. Tinospora cordifolia: one plant, many roles. Anc Sci Life. 2012;31(4):151-9. Available http:www.ncbi.nlm.nih.gov/pmc/articles/PMC36447 51. Accessed on 24 May 2016.

11. Pandey M, Chikara SK, Vyas MK, Sharma R. Tinospora cordifolia: a climbing shrub in health care management. Int J Pharm Bio Sci. 2012;3(4):612-28.

12. Malve HO, Raut SB, Marathe PA. Effect of combination of Phyllanthus emblica, Tinospora cordifolia, and Ocimum sanctum on spatial learning and memory in rats. Journal of Ayurveda and Integrative Medicine. 2014;5(4);209-15.

13. CNS stimulants and cognitive enhancers. K. D. Tripathi. Essentials of Medical Pharmacology, $7^{\text {th }}$ edition, New Delhi: Jaypee Brothers medical publishers (P) Ltd: 2013:486-91.

Cite this article as: Jyothi $\mathrm{CH}$, Shashikala $\mathrm{G}$, Vidya HK, Shashikala GH. Evaluation of effect of alcoholic extract of Tinospora cordifolia on learning and memory in alprazolam induced amnesia in albino mice. Int $\mathrm{J}$ Basic Clin Pharmacol 2016;5:2159-63. 